\title{
Analysis of the economic and environmental benefits through the reverse logistics for retail
}

\author{
Renata Borini Marcondes e Santos ${ }^{1,}$, , Sergio Silva Braga Junior ${ }^{1}$, Dirceu da Silva ${ }^{2}$, \\ Eduardo Guilherme Satolo ${ }^{1}$ \\ ${ }^{1}$ UNESP - Univ. Estadual Paulista, Tupa Câmpus, Sao Paulo, Brazil \\ ${ }^{2}$ UNINOVE - Universidade Nove de Julho, Postgraduate Program in Management, Sao Paulo, Brazil \\ Email adress: \\ renata_borini@hotmail.com (R. B. M. e Santos), sergio@tupa.unesp.br (S. S. B. Junior), dirceuds@gmail.com (D. da Silva), \\ eduardo@tupa.unesp.br (E. G. Satolo)
}

\section{To cite this article:}

Renata Borini Marcondes e Santos, Sergio Silva Braga Junior, Dirceu da Silva, Eduardo Guilherme Satolo. Analysis of the Economic and Environmental Benefits through the Reverse Logistics for Retail. American Journal of Environmental Protection. Vol. 3, No. 3, 2014, pp. 138-143. doi: 10.11648/j.ajep.20140303.15

\begin{abstract}
The growing consumption has generated a lot of waste to be discarded and consequently raise the degree of pollution of the planet. In this sense, this research aims to analyze the environmental gains with the practice of reverse logistics in retail and quantify cardboard and plastic volumes that ceases to be disposed in landfills. To quantify the environmental gain, Wuppertal method, which quantifies the non-contaminated waste, was used to measure the economy of water and air by the interviewed companies. This research was raised the volume of waste recycled by four Brazilian supermarkets. The volume generated is representative and the environmental gains are evident. Results show that within the retailing reverse logistics is a practice that adds value and creates sustainability in jail on other processes connected to it.
\end{abstract}

Keywords: Waste Management, Reverse Logistic, Retail, Sustainability

\section{Introduction}

The world market behaves increasingly globalized form, since the information circulating from one continent to another, even in relation to the goods. This globalization has stimulated, with great intensity, the consumerism that is powered by the production of new goods that generate more waste to be discarded.

The generation of waste has increased throughout the supply chain, from industry and arriving at retail, where direct contact with consumers occurs. Thus, the most appropriate way to engage the social, environmental and economic aspect to deal with the discarded material is reverse logistics (Santos, 2012).

Reverse logistics includes the reverse flow of materials that previously did not offer many utilities and treated as junk, trash or waste, according to Braga Junior et al. (2011). From the implementation and control of reverse logistics such residues back to the retail supply chain to feed some link or entering as raw material, as demonstrated Nunes and Haddad (2013) show that waste management in the oil and gas industry.

Reverse logistics is now recognized as an area of logis- tics business that plans, operates and controls the flow and logistics information corresponding to the return of after-sales and post-consumer goods to the production cycle. It is use enables the recycling of support resources used by retailers and thus ensure the return of these materials to the production process to reduce the environmental impact.

In this sense, the objective of the research was to analyze the opportunities generated by the reverse logistics and measure their economic and environmental advantages for retailers. This study investigated four Brazilian supermarkets, located in São Paulo. As a result, it was observed the companies has processing huge volumes of waste generated, that return to production chain. In this sense, retail has contributed to reducing the environmental impact that could be left by these residues.

\section{Literature Review}

\subsection{Reverse Logistics}

Having your main focus tied to the return of goods to be processed through the recycling of materials, the concept of reverse logistics is a process of planning, implementing and 
controlling the flow of raw materials, there is stock in process and finished (products and your information flow) from the point of consumption to the point of origin for the purpose of acquiring the value that could be lost or conduct proper disposal (Rogers \& Tibben-Lembke, 1998; Oliveira \& Silva, 2005; Marchi, 2011).

For Oliveira et al (2012) reverse logistics has emerged as the relocation of function of materials and waste, one of whose main objectives is the collection and replacement of the same distribution channels, and thus promoting significant economic gains, and add greater environmental gains value to the product.

Oliveira e Silva (2005) adds that reverse logistics has significant representation on the actions aimed at preserving the environment, aiming at sustainable development. The efficient planning of this process has become essential not only for companies but also for society because of the solid waste becomes a problem for cities (Sankoh \& Yan, 2013).

This reverse process is directly linked to recycling, which is largely responsible for a significant part of the waste that becomes raw again. In this sense, Oliveira and Silva (2005) explain that the activities of the reverse logistics depend on the material and the reason they enter the system. The materials can be divided into two major groups: products and packaging. For products, the flow of reverse logistics will be a need to repair, recycling, or because they simply return the customers. Have the packages are usually directed to the beginning of the production process turned into raw material.

There are four main reasons for performing the reverse logistics, according to De Brito \& Dekker (2004), a) legal issues which require establishments to position itself to the problems generated by the disposal of waste; b) environmental awareness, which brings the concept of sustainability linked the actions of the studied logistics and the collection made by the consumer; c) strategic differentials interfere in company image, flexibility and quality in receiving products/waste customers d) cost reduction, revenue generation through material that would otherwise be discarded.

Oliveira e Silva (2005) also claim that it is possible by observing the reverse process to identify materials that can return a number of ways, such as: a) return to the supplier when agreements; b) be resold if they are still appropriate marketing conditions; c) be reconditioned, provided there is the economic justification; d) be recycled if there is no possibility of recovery. All these alternatives generate reclaimed materials that come in direct new logistics system. In the latter case, the target may be their final disposal.

This product return obeys some steps, cited by Leite (2009, 2011), which briefly are: collection, selection of destinations of the products or waste, reuse and distribution of these new products to market. However, how these steps are performed interfere with the progress of an efficient process, which would be the realization of the goal of reverse logistics, reuse materials so they do not harm the environment.

\subsection{Recycling and Reuse of Solid Waste}

The high degree of consumption and population growth have been largely responsible for the uncontrolled increase of solid waste disposal, consequently causes an ecological imbalance increases the rate of pollution on the planet (Santos, 2012; Ahmeduzzaman \& Rahman, 2013; Worsley, Wang \& Ridley, 2014). Thus, they are seen as one of the greatest problems faced in a society in pursuit of sustainable development (Santos, 2012; Sankoh \& Yan, 2013).

Through these statements, and yet according to Santos (2012), defined as solid waste, in general, undesirable materials for those who ruled them from various types of activities and locations, which may cause serious risks to the health and well environmental and human being, if they are disposed of improperly.

Araújo et al. (2010) argue that solid wastes are all remnants of human activities or food scraps, packaging, plastics and others. It is all that is deemed undesirable disposable or even useless. However, what has value for some, may have a benefit to others.

Disposal of these wastes have significant risks, especially in developing areas, therefore, must its destination and form of reuse is correct (Marchi, 2011).

\section{Methodological Procedures}

For the verification of the objectives proposed by the present study, exploratory qualitative research through multiple cases where a semi-structured questionnaire and participant observation in the data collection process was used was performed. As a quantitative nature is justified by measure economic and environmental advantage of implementing reverse logistics in supermarkets studied. Figure 1 presents the methodological procedures used for this research and then the details of this process occurs.

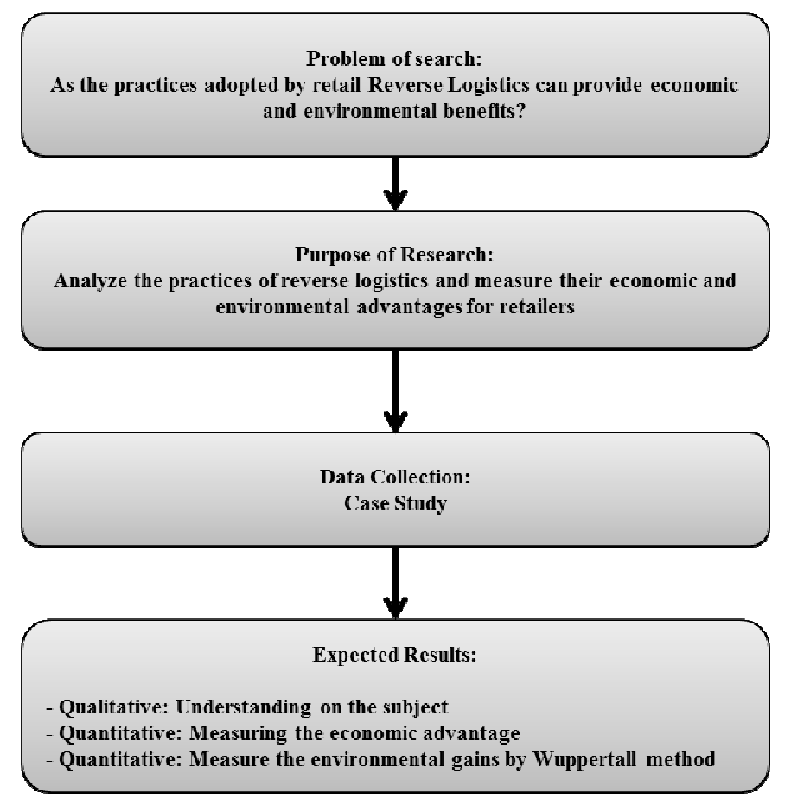

Figure 1. Methodological Procedures for this project 
As the use of qualitative and quantitative method, qualitative method, following the exploratory nature with a non-probability convenience sampling (Cooper \& Schindler, 2003). So, Cooper \& Schindler (2003) explains that qualitative research is characterized as a comprehensive and detailed approach to the meanings and situational characteristics presented by interviewees and the cases analyzed, rather than producing quantitative measures or behavioral characteristics.

On the quantitative method, the data regarding the amount of recycled material and economic gains with this action have been raised. Of course, these are not recycled materials when discharged into the environment giving rise to the study of the environmental benefits. The environmental benefits were measured at Wuppertal method published for Ritthoff, Rohn \& Liedtke (2002).

The method, developed by the Wuppertal Institute, can assess the environmental changes associated with resource extraction from their natural ecosystems. Thus, for the supply with material flow system, a larger quantity of material previously processed in various environmental compartments. The compartments are classified as: abiotic, biotic, water and air.

According to Odum (1998) The ecosystem is composed of biotic and abiotic compartments interact with each other, the biotic compartment is the set of all living organisms like plants and decomposers, the abiotic compartment is the set of non-living factors in an ecosystem, but influencing the biotic environment, consists of temperature, pressure, rainfall relief, among others. The total quantity of material in each compartment was processed to supply a material called material intensity. To determine the intensity of the material, the inlet mass flow (expressed in the appropriate units) is multiplied by MIF (mass intensity factors) factor is the amount of material required to produce one unit of the input stream.

The objective of the research was to demonstrate the economic and environmental advantages in the implementation of reverse logistics in the retail market. To achieve the proposed objective a study will be conducted in the cities of Mogi das Cruzes, Tupa and Marilia State of Sao Paulo/Brazil in a supermarket each city to compare quantities and types of waste that is collected by means of reverse logistics. The choice of supermarket was accomplished through a formal invitation to the biggest supermarket in each city. Thus, with a commitment to maintain the confidentiality of the name and address not only strategic to the core business, the invitation was accepted. The surveyed cities have a total population of approximately 1 million people and supermarkets represent purchases approximately $50 \%$ of this population.

A method to analyze the collected data, developed by the Wuppertal Institute, can assess the environmental changes associated with resource extraction from their natural ecosystems. Thus, to supply a flow of material from one system, a larger quantity of material previously processed in various environmental compartments. The compartments are classified as: abiotic, biotic, water and air.

Importantly, studies of the intensity of the material developed in Wuppertal Institute are based on the energy mix in Germany, Europe or the World. However, that fact does not preclude the implementation of this methodological tool in Brazil, according to the institute's figures are very close.

\section{Characterization of Supermarkets A, $B$ and $C$}

By being in a strategic location, the average daily flow of people in supermarkets A and B, is 6100 and 6900, respectively. Currently, the three supermarkets have in their areas of sales sections of grocery, general merchandise, grocery, bazar, bakery, deli, butcher, cold area (dairy, poultry, fish). Since the store's feature $3000 \mathrm{~m}^{2}$ with 32 checkouts and B of $3500 \mathrm{~m}^{2}$ with 37 checkouts.

The third store the largest, $\mathrm{C}$, is located in the city of Mogi das Cruzes, and has 43 checkouts a sales area of $3500 \mathrm{~m}^{2}$ and higher average daily flow of people, 8000 . Based on these data, all supermarkets fall as superstore as ranked by Parente (2000), when it comes to shopping for food retailing format. This classification follows the variation of the number of check-outs and sales area.

Through this study, it can be seen that the three supermarkets have a structure for processing and storage of waste collected in the supermarket, thereby facilitating the gathering of the materials (cardboard and plastic) are recycled.

The frequency of waste collection varies from one store to another, depending on the agreement that was made with the waste company. The store $\mathrm{B}$ and $\mathrm{C}$ has a daily frequency of collection, since the accumulation of waste is great. Since the supermarket A, on average three times a week.

\section{Search Results}

The great accumulation of solid waste caused by increased consumption in retail has led to increased production of materials that were not recycled, reused and not recovered. This situation has reached the retail supermarket companies for being one of the production chains and is directly linked to the consumer. Accordingly, the most appropriate mechanism to be adopted by retailers to meet this need, it may be practical to reverse logistics.

This mechanism meets the call of environmental management tending to business sustainability and create a new business opportunity in the sector and generate possibilities for financial gain. Some retailers seek agreements with its suppliers to return plastic and cardboard for the industry, others establish contracts with recycling companies to perform the correct destination.

Table 1 shows the total annual volume of cardboard and plastic from retailers $\mathrm{A}, \mathrm{B}$ and $\mathrm{C}$ and return the supply chain through recycling or reuse.

The process of recycling and reuse these materials to be 
disposed of at retail is shown in Figure 2 which shows the flow of the waste accumulated in the supermarket chain is inserted. Processes of reusing sale of cardboard and plastic, and these are presented the products that aggregate financial income by selling and ease of replacement in the market.

Table 1. Total volume of cardboard and recycled plastic in 2013

\begin{tabular}{ll}
\hline Type of Waste & Volume \\
\hline Cardboard & 900.000 \\
Plastic & 90.000 \\
Total & 990.000 \\
\hline
\end{tabular}

The process of reverse logistics cited these materials begin when suppliers deliver products packaged in cardboard boxes and pallets, protected by plastic. The supermarket receives and to carry supplies to the shelves, cardboard and plastic separates and returns to the depot where it is separated, compressed and stored in bales area. They are sold to a company that prepares the material in order to be transformed back into the packaging and subsequently sold to industries supplying the supermarket.

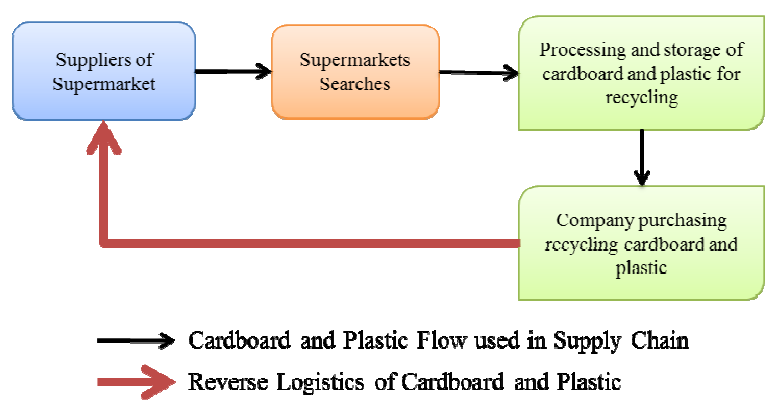

Figure 2. Structure of the Reverse Logistics chain supermarkets studied

\subsection{Economic Advantage}

The financial gains produced by the implementation of reverse logistics are presented in Table 2. Counting data from supermarket A, B and C, one can observe that together add up to a total of approximately US\$ 81,000 for cardboard and plastic to US\$23,000. These values are usually transformed into benefits for local society.

Table 2. Total volume of cardboard and recycled plastic in 2013

\begin{tabular}{llll}
\hline \multicolumn{2}{l}{ Economic Advantage (US\$) } & & \\
Supermarket & Cardboard & Plastic & Total \\
\hline A & $23,243.00$ & $8,100.00$ & $31,343.00$ \\
B & $26,759.00$ & $9,370.00$ & $36,129.00$ \\
C & $31,108,00$ & $10,900.00$ & $42,008.00$ \\
Total & $81,000.00$ & $28,370.00$ & $\mathbf{1 0 9 , 3 7 0 . 0 0}$ \\
\hline
\end{tabular}

As the total amounts of cardboard and plastic are shown, it is also important to emphasize the economic advantage gained by each supermarket by adding these two materials. This way, you can view the total amount annually collects only through the practice of reverse logistics of cardboard and plastic.
In this period, the average prices paid to supermarkets were different for each one according to the city in which it is located. Table 3 below show the values negotiated for the sale of both the cardboard and the plastic for the supermarket $\mathrm{A}, \mathrm{B}$ and $\mathrm{C}$.

Table 3. Traded Price (2013)

\begin{tabular}{lll}
\hline \multicolumn{2}{l}{ Prices paid during 2013} & \\
\hline \multirow{2}{*}{ A } & Value kilogram of Cardboard & US $\$ 0,08$ \\
& Value Plastics kilogram & US $\$ 0,22$ \\
\multirow{2}{*}{ B $\quad$ Value kilogram of Cardboard } & US $\$ 0,09$ \\
& Value Plastics kilogram & US $\$ 0,32$ \\
\multirow{2}{*}{ C $\quad$ Value kilogram of Cardboard } & Value Plastics kilogram & US 0,10 \\
& & US $\$ 0,41$ \\
\hline
\end{tabular}

Table 4, below, displays the calculated average of the prices paid in 2013 for $\mathrm{A}, \mathrm{B}$ and $\mathrm{C}$.

Table 4. Prices calculated between A, B and C (2013)

\begin{tabular}{lll}
\hline \multicolumn{3}{|c}{ Prices calculated between A, B and C (2013) } \\
\hline \multirow{2}{*}{$A, B$ and C } & Value kilogram of Cardboard & US\$ 0,09 \\
& Value Plastics kilogram & US 0,32 \\
\hline
\end{tabular}

The data outlined in Table 3 show that there is variability in the amounts paid by the companies for the different supermarkets, this being related to variation in which the city is located retail, and management model adopted. However, it is observed that the average value is practiced in cardboard and plastic market.

\subsection{Environmental Advantage}

Through Wuppertal method, it was possible to perform the calculation that estimates how much of biotic material ceases to be produced and how abiotic material ceases to be released into the environment, providing an environmental gain. The reference values are presented in Table 5. These values were structured by the Wuppertal Institute, which measured the abiotic and biotic material generated from plastic and cardboard to determine how much a company ceases to pollute when implementing a process of Reverse Logistics for these materials. For clarification, the plastic is a product that does not generate biotic material.

Table 5. Factors (European) Intensity Material

\begin{tabular}{lllll}
\hline \multicolumn{2}{l}{ Factors (European) } & \multicolumn{3}{l}{ Intensity Material } \\
Material & $\begin{array}{l}\text { Material } \\
\text { Mabiotic }\end{array}$ & biotic & Water & Air \\
\hline Plastics (g/g) & 6.45 & - & 294.20 & 3.72 \\
Cardboard (g/g) & 1.86 & 0.75 & 93.60 & 0.33 \\
\hline
\end{tabular}

To determine the intensity of the material, the inlet mass flow (expressed in units corresponding) is multiplied by MIF (mass intensity factors) factor corresponding to the amount of material required to produce one unit of the input stream. MIF values are shown in Table 5.

The retail, the total mass of material (MM) was 55928.57 
$\mathrm{kg}$ monthly for and $13821.43 \mathrm{~kg}$ cardboard to plastic. These figures are the result of the sum of the values of both abiotic and biotic materials presented in Table 6. Processed For high impact on the volume of water and air that are no longer polluted volume is significant, as a result.

Table 6. Environmental benefits of reuse packaging process Supermarket " $A$ " in kilogramg

\begin{tabular}{lcccl}
\hline \multicolumn{4}{l}{ Material Intensity Factors - Supermarket “A” } \\
Material & $\begin{array}{c}\text { Material } \\
\text { abiotic }\end{array}$ & $\begin{array}{l}\text { Material } \\
\text { biotic }\end{array}$ & Water & Air \\
\hline $\begin{array}{l}\text { Plastics } \\
\text { (kg/kg) }\end{array}$ & $165.857,14$ & & $7.565 .142,86$ & $95.734,29$ \\
$\begin{array}{l}\text { Cardboard } \\
\text { (kg/kg) }\end{array}$ & $478.285,71$ & $192.857,14$ & $24.068 .571,43$ & $83.571,43$ \\
Total & $644.142,86$ & $192.857,14$ & $31.633 .714,29$ & $179.305,71$ \\
\hline
\end{tabular}

Regarding the supermarket $\mathrm{B}$, the total quantity of material per month was $64667.41 \mathrm{~kg}$ to $15981.03 \mathrm{~kg}$ and cardboard to plastic. So, from the amount of cardboard and recycled plastic, it can be stated that approximately 31,000 tons of water, and 1,200 tons of air no longer polluted, as Table 7.

Table 7. Environmental benefits of reuse packaging process Supermarket " $B$ " in kilogramg

\begin{tabular}{lclll}
\hline \multicolumn{4}{l}{ Material Intensity Factors - Supermarket "B" } & \\
Material & $\begin{array}{c}\text { Material } \\
\text { abiotic }\end{array}$ & $\begin{array}{l}\text { Material } \\
\text { biotic }\end{array}$ & Water & Air \\
\hline $\begin{array}{l}\text { Plastics } \\
\text { (kg/kg) }\end{array}$ & $191.772,32$ & & $8.747 .196,43$ & $110.692,77$ \\
$\begin{array}{l}\text { Cardboard } \\
\text { (kg/kg) }\end{array}$ & $553.017,86$ & $222.991,07$ & $27.829 .285,71$ & $1.106 .927,68$ \\
Total & $744.790,18$ & $222.991,07$ & $36.576 .482,14$ & $1.217 .620,45$ \\
\hline
\end{tabular}

The environmental benefit that offers $\mathrm{C}$ has a total mass of material per month was $75154.02 \mathrm{~kg}$ for cardboard and plastic to $18572.55 \mathrm{~kg}$. This supermarket had the highest volume collects plastic and cardboard between the three surveyed about the practices of reverse logistics.

Table 8. Environmental benefits of reuse packaging process Supermarket " $C$ " in kilogramg

\begin{tabular}{lccll}
\hline \multicolumn{3}{l}{ Material Intensity Factors - Supermarket "C" } \\
Material & $\begin{array}{c}\text { Material } \\
\text { abiotic }\end{array}$ & $\begin{array}{c}\text { Material } \\
\text { biotic }\end{array}$ & Water & Air \\
\hline $\begin{array}{l}\text { Plastics } \\
\text { (kg/kg) }\end{array}$ & $222.870,54$ & & $10.165 .660,71$ & $128.642,95$ \\
$\begin{array}{l}\text { Cardboard } \\
(\mathrm{kg} / \mathrm{kg})\end{array}$ & $642.696,43$ & $259.151,79$ & $32.342 .142,86$ & $112.299,11$ \\
Total & $865.566,96$ & $259.151,79$ & $42.507 .803,57$ & $240.942,05$ \\
\hline
\end{tabular}

Accordingly, the total ceased to be released into the environment to abiotic material is over 865 tons to about 260 tons to biotic material, as shown in Table 8 .

From the analysis of the data collected and presented, it was possible to observe the great importance that the practice of reverse logistics presents for the sustainability of retail and supply chain industry with respect to global warming, the depletion of the ozone layer and the pressure
Atmospheric. This consideration is also based on consolidated data of Table 1 shows that the total volume of 990 tons of plastic and cardboard only in 2013 for the three supermarkets surveyed resulting in a huge amount of waste they no longer take up space in landfills or be destinations not appropriate locations for disposal.

Table 9 shows that the consolidated figures of the environmental benefit provided by summing the results of all supermarkets surveyed together groups an amount of more than a thousand tons of abiotic materials and 675 tons of biotic material (which cease to pollute vegetation, soil and natural) decomposers.

Table 9. Total Values of environmental benefits $(\mathrm{kg})$

\begin{tabular}{lcccl}
\hline \multicolumn{5}{l}{ Material Intensity Factors - Supermarket “A, B and C" } \\
Material & $\begin{array}{c}\text { Material } \\
\text { abiotic }\end{array}$ & $\begin{array}{c}\text { Material } \\
\text { biotic }\end{array}$ & Water & Air \\
\hline $\begin{array}{l}\text { Plastics } \\
(\mathrm{kg} / \mathrm{kg})\end{array}$ & 580.500 & & 26.478 .000 & 335.070 \\
$\begin{array}{l}\text { Cardboard } \\
(\mathrm{kg} / \mathrm{kg})\end{array}$ & 1.674 .000 & 675.000 & 84.240 .000 & 1.302 .798 \\
Total & 2.254 .500 & 675.000 & 110.718 .000 & 1.637 .868 \\
\hline
\end{tabular}

In this sense, the 990 tons of cardboard and plastic no longer pollute more than 110 tons and 1600 tons of water from the air, even in $\mathrm{CO} 2$ emissions. In this respect, the environmental gain analyzed in this study can be quantified as follows: for each $\mathrm{kg}$ of recycled waste that this study has raised, $2.3 \mathrm{~kg}$ of abiotic material, $0.69 \mathrm{~kg}$ of biotic material ceases to be generated, $111 \mathrm{~kg}, 1.65 \mathrm{~kg}$ of water were not polluted.

\section{Conclusions}

With the increase of waste generation, the purpose of this study was to analyze the reverse logistics to reduce the impact caused by pollution. The retail sector has been researched because it establishes direct contact with the consumer and engages the social, environmental and economic aspects in the proposal to deal with the discarded material in this segment (Santos, 2012).

Whereas one of the main goals of reverse logistics is the collection and replacement of materials and waste in distribution channels, promoting economic, environmental gains and adding more value to the product, this process has significant representation in preserving the environment.

As a function, Reverse Logistics seeks to promote mainly the recycling of solid waste, to be disposed of properly and help to minimize the risks to health and the environment.

In this sense, the results of this study showed that reverse logistics is a process that contributes to sustainability in the retail market, by bringing economic gains with material that would be discarded, but that starts to generate additional revenue. Through this analysis, it can be observed that the $\mathrm{C}$ supermarket, located in the city of Mogi das Cruzes, Sao Paulo/Brazil, has the largest financial donations, to generate higher volume and have a dedicated waste management. Then B, located in Marilia, State of Sao Paulo/Brazil, has the 
second highest revenue and volume of waste, also the same characteristics for waste management was observed.

In addition to economic gain, reverse logistics provides environmental benefits, which are more attractive. In this analysis, the supermarket select more waste is getting higher economic benefits, demonstrating that the variables that define the size of retail are proportional to earnings.

According to the analysis in the environmental advantages item, relating to the large amount of waste properly, it can be assumed that only the retail of the state of Sao Paulo/Brazil should generate millions of tons of cardboard and plastic, whereas only three supermarkets generate a volume of nearly a thousand tons per year, this being one of the main highlights of this review.

A limitation of this study is found on the calculation of the intensity of the material developed in Wuppertal Institute that uses as a basis the energy matrix of Germany, Europe or the World. However, on the other hand, does not preclude the implementation of this methodological tool in Brazil. According to the institute, the quantitative data are very close and do not show how accuracy is only a means to quantify the environmental benefits, as being of great value to the scientific context. Can be considered another limitation of cases the possibility that the organization does not have economic advantages occur, but the costs of sustainability can be procured for their actions recycling and proper disposal of solid waste.

Finally, the contribution of this study is the knowledge of how the solid waste generated by most supermarkets through the Reverse Logistics and retailers who apply are not yet treated, demonstrate that this can be an alternative of direct economic gains and environmental gains to society in the search for sustainability.

\section{Acknowledgements}

Process no 2013/16454-0, São Paulo Research Foundation FAPESP for financial support to the survey.

\section{References}

[1] Araujo, C. B. D., Zambon, M. M., Silva, N. F. D., \& Rizzo, M. R. (2012). Logística reversa: um estudo em supermercados de cidades do interior paulista. Periódico Eletrônico Fórum Ambiental da Alta Paulista, 6(4).

[2] Braga Junior, S. S., Alonso Junior, N., Ramos, A. L., Evangelista, A. A. \& Silva, D. (2011). Um Estudo da Logistica Reversa no Grupo Carrefour: Gestão e Prática em um Supermercado na Cidade de São Paulo. Revista Emprendedorismo y Estrategia Organizacional, 1(3), p. 69-85.

[3] Cooper, D. R. Schindler. PS (2003). Business Research Methods. McGrawHill Companies.
[4] De Brito, M. P., \& Dekker, R. (2004). A framework for reverse logistics (pp. 3-27). Springer Berlin Heidelberg.

[5] de Oliveira, A. A., \& SILVA, J. T. M. (2011). A Logística Reversa no Processo de Revalorização dos Bens Manufaturados. REA-Revista Eletrônica de Administração, $4(2)$.

[6] Leite, P. R. (2009). Logística reversa: meio ambiente e competitividade. Pearson Prentice Hall.

[7] Leite, P. R. (2011). Logística reversa: A complexidade do retorno de produtos. CLBR-Conselho de Logística Reversa do Brasil, disponível em http://www.clrb.com.br/artigos.

[8] Marchi, C. M. D. F. (2011). Cenário mundial dos resíduos sólidos eo comportamento corporativo brasileiro frente à logística reversa. Perspectivas em Gestão \& Conhecimento, 1(2), 118-135.

[9] Nunes, E. C., \& Haddad, A. N. (2013). Waste management in the oil and gas industry by Brazilian Guideline for Environmental Audits-DZ-056-R. 3. American Journal of Environmental Protection, 2(6), 170-175. doi: 10.11648/j.ajep.20130206.18

[10] Odum, E.P. (1988). Ecologia. Editora Guanabara Koogan, Rio de Janeiro-RJ.

[11] Oliveira, F., Oliveira, E., \& Rodrigues, E. F. (2012). Logística reversa e sustentabilidade: gargalos ea importância diante do cenário competitivo.Revista Científica da Ajes, Juína, 3(6).

[12] Parente, J. (2000). Varejo no Brasil: gestão e estratégia. Editora Atlas.

[13] Rahman, M. N., \& Ahmeduzzaman, M. (2013). Case study on the recent solid waste management scenario in Rajshahi city, Bangladesh. American Journal of Environmental Protection, 2(2), 58-63. doi: 10.11648/j.ajep.20130202.15

[14] Ritthoff, M., Rohn, H., \& Liedtke, C. (2002). Calculating MIPS: Resource productivity of products and services (No. 27e). Wuppertal Spezial, Wuppertal Institut für Klima, Umwelt und Energie.

[15] Rogers, D. S., \& Tibben-Lembke, R. S. (1998). Going Backwards: Reverse Logistics Trends and Practices. University of Nevada. Reno Center for Logistics Management. Reverse Logistics Executive Council, 101-15.

[16] Sankoh, F. P., \& Yan, X. (2013). Problems of solid waste management in developing urban cities: a case study of Freetown, Sierra Leone. American Journal of Environmental Protection, 2(5), 113-120. doi: 10.11648/j.ajep.20130205.11

[17] Santos, J. G. (2012). A Logística Reversa Como Ferramenta Para a Sustentabilidade: um estudo sobre a importância das cooperativas de reciclagem na gestão dos resíduos sólidos urbanos. REUNA, 17(2), p-81.

[18] Worsley, A., Wang, W., \& Ridley, S. (2014). Australian consumers' perceptions of environmental and agricultural threats: The associations of demographic and of psychographic variables. American Journal of Environmental Protection, 3(1), 10-18. doi: 10.11648/j.ajep.20140301.12 